\title{
PENINGKATAN PENGELOLAAN KEUANGAN DAN AKUNTANSI BUMDES DESA PULAU PANGGUNGKECAMATAN TALANG EMPAT BENGKULU TENGAH
}

\author{
Zahrah Indah Ferina, Siti Hanila, Yun Fitriano, Neri Susanti, Ahmad Soleh \\ Fakultas Ekonomi Universitas Dehasen Bengkulu \\ *Corresponding author: Zahrah Indah Ferina \\ zahrahindah@unived.ac.id
}

ABSTRAK

Terdapat potensi yang dimiliki desa yang selama ini kurang dikelola oleh desadikarenakan desa belum memiliki modal untuk mengelola pontensi yang ada. Hal ini menjadi salah satu sorotan dari pemerintah pusat. Maka dari itu terbitlah UndangUndang Desa yang memberikan kesempatan desa untuk mengelola desa itu sendiri secara mandiri dan profesional. Terbetuknya usaha bisnis desa atau biasa disebut Badan Usaha Milik Desa (BUMDes/BUMDesa) diharapkan menjadi cikal bakal penggerak perekonomian ini dengan cara memaksimalkan pengembangan potensi desa yang ada.Akan tetapi timbul masalah selanjutnya yaitu Permasalahan Sumber Daya Manusia (SDM), masih rendahnya SDM yang dimiliki BUMDes terkait pengelolaan keuangan dan akuntansi BUMDes.BUMDes diharapkan menjadi penggerak perekonomian di desa tersebut, menyerap sebanyak-banyak tenaga kerja untuk warga desa. Untuk itu dosen memiliki kewajiban Tridharma perguruan tinggi, salah satunya melakukan pengabdian kepada masyarakat ini mencoba memberikan solusi dari permasalahan tersebut. Desa Pulau Panggung sebuah desa yang berada di kecamatan Talang Empat Bengkulu Tengah memiliki potensi yang besar akan tetapi belum dikelola dengan baik. Dengan memberikan lokakarya tentang laporan keuangan dan memberikan pendampingan secara terus menerus kepada desa di harapkan memiliki output pengurus BUMDes yang mumpuni dalam mengelola BUMDes terutama dibidang keuangan. Lokakarya ini memberikan materi tentang laporan keuangan yang sesuai standar akuntansi keuangan yaitu SAK-ETAP.

\section{PENDAHULUAN}

Badan Usaha Milik Desa (BUMDes) merupakan badan usaha yang digagas oleh pemerintah, dimana BUMDes ini diharapkan menjadi stimulus untuk meningkatkan perekonomian yang ada didesa. Sebagai suatu badan usaha maka BUMDes wajib untuk membuat laporan keuangan. Laporan keuangan merupakan alat untuk mengkomunikasikan bagaimana keadaan keuangan kepada pemilik atau pihak stakeholder. Laporan keuangan yang baik dapat dijadikan alat sebagai bahan komunikasi dan evaluasi untuk going 
concern BUMDes kedepan. Dalam laporan keuangan tercermin struktur modal dan laba atau rugi BUMDes..

Desa dapat mendirikan BUMDes dengan mempertimbangkan beberapa faktor yakni : 1) inisiatif pemerintah Desa dan/atau masyarakat Desa; 2) potensi usaha ekonomi Desa; 3) sumberdaya alam di Desa; 4) sumberdaya manusia yang mampu mengelola BUMDes; 5) penyertaan modal dari Pemerintah Desa dalam bentuk pembiayaan dan kekayaan Desa yang diserahkan untuk dikelola sebagai bagian dari usaha BUMDes (Permendesa No. 4 Tahun 2015).

Berdasarkan Peraturan Menteri Desa, Pembangunan Daerah Tertinggal dan Transmigrasi Nomor 4 Tahun 2015 tentang Pendirian, Pengurusan dan pengelolaan, dan pembubaran Badan Usaha Milik Desa (BUMDesa) pasal 12 ayat (3) bahwa pelaksanaan operasional berwenang : (1) Membuat laporan keuangan seluruh unit-unit usaha BUMDes setiap bulan, (2) Membuat laporan perkembangan kegiatan unit-unit usaha BUMDes setiap bulan (3) Memberikan laporan perkembangan unit-unit usaha BUMDes kepada masyarakat Desa melalui musyawarah Desa sekurang-kurangnya 2 (dua) kali dalam 1 (satu) tahun. Berdasarkan Permendes Nomor 4 Tahun 2015 tersebut, maka laporan keuangan BUMDes meliputi neraca, laporan laba rugi, laporan perubahan ekuitas, laporan perubahan posisi keuangan yang dapat disajikan berupa laporan arus kas atau laporan arus dana, dan catatan laporan lain serta materi penjelasan yang merupakan bagian integral dari laporan keuangan.

BUMDes dalam menyusun laporan keuangan harus memperhatikan dengan jelas standar keuangan yang digunakan, artinya dalam penyusunan laporan keuangan BUMDes harus mengacu pada peraturan yang telah ditetapkan yaitu Standar Akuntansi Keuangan Entitas Tanpa Akuntabilitas Publik(SAK ETAP). Dalam SAK ETAP (2013) pada bab 3 tentang penyajian laporan keuangan dinyatakan bahwa laporan keuangan lengkap suatu entitas terdiri dari : neraca, laporan laba rugi, laporan perubahan ekuitas, laporan arus kas, dan catatan atas laporan keuangan. 
Ini artinya bahwa BUMDes harus

menyusun laporan keuangan secara lengkap sesuai dengan SAK ETAP. Tujuan dari penyusunan SAKETAP bukan hanya sebagai standar akuntansi keuangan yang layak bagi perusahaan kecil dan menengah atau perusahaan yang belum go public termasuk BUMDes. Pembuatan laporan keuangan harus bersifat jujur dan transparan. BUMDes juga wajib memberikan laporan perkembangan unit-unit usaha BUMDes kepada masyarakat desa melalui musyawarah desa sekurangkurangnya dua kali dalam satu tahun.

Pasal 88 ayat (1) Pendirian BUMDes disepakati melalui musyawarah Desa, ayat (2) Pendirian BUMDes sebagaimana dimaksud pada ayat (1) ditetapkan dengan Peraturan Desa. MenurutPermendesa PDTT Nomor 4 Tahun 2015 tentang pendirian, pengurusan, dan pengelolaan, dan pembubaran Badan Usaha Milik Desa.Dalam pengelolaan laporan keuangan masih banyak BUMDes yang sudah berkembang di Indonesia yang belum menerapkan SAK ETAP dalam menyusun laporan keuangan. Hal ini dibuktikan dalam penelitian Rudini dan Nurhayati (2011) dari laporan keuangan pada BUMDes Langkitin hanya terdiri dari Laporan Laba Rugi dan Neraca.

BUMDes merupakan kegiatan untuk menjalankan usaha di desa. jenis usaha yang meliputi pelayanan ekonomi desa seperti: a. Usaha jasa keuanganm jasa angkutan darat dan air, listrik desa, dan usaha sejenis lainnya; b. Penyaluran Sembilan bahan pokok ekonomi desa; c. Perdagangan hasil pertanian meliputi tanaman pangan perkebunan peternakan perikanan, dan agrobisnis; d. Industri dan kerajinan rakyat

Menurut Hidayat(2018) Ada beberapa ciri BUMDes yang membedakannya dengan organisasi bisnis yang lain yaitu: 1. Kekuasaan penuh di tangan desa, dan dikelola bersama masyarakat desa 2. Modal bersama yakni bersumber dari desa dan masyarakat, dilakukan dengan cara penyerataan modal. 3. Menggunakan falsafah bisnis yang berakar dari budaya lokal untuk melakukan kegiatan operasional. Proses operasionalisasi ini di kontrol bersama oleh BPD,Pemerintah Desa dan anggota masyarakat. 4. Untuk 
bidang yang dipilih bagi badan usaha desa disesuaikan dengan potensi dan informasi pasar. 5. Keuntungan yang diperoleh dari produksi dan penjualan ditujukan untuk meningkatkan kesejahteraan anggota dan masyarakat desa melalui kebijkan desa. 6. Pemberian fasilitas dan pengawasan dilakukan oleh Pemerintah Provinsi, Pemerintah Kabupaten, dan Pemrintah Desa.

Pengelolaan keuangan dan akuntansi BUMDes merupakan suatu hal yang berbeda. Pengelolaan keuangan dimulai dari penyusunan anggaran. Dimana akun modal diletakan ketika dana desa diberikan kepada BUMDes. Selanjutnya akuntansi BUMDes yang sesuai standar merupakan suatu keharusan dimana laporan keuangan yang baik dapat menunjukan kinerja keuangan yang baik pula.

Desa Pulau Panggung kecamatan Talang Empat Bengkulu Selatan merupakan desa binaan dalam kegiatan pengabdian kepada masyarakat Fakutas Ekonomi Universitas Dehasen Bengkulu. Desa ini hanya ditempuh 40 menit dari pusat kota. Permasalahan desa ini yaitudimana desa ini masih membutuhkan edukasi tentang laporan keuangan dan akuntansi BUMDes. Sumber daya manusia yang belum terampil dan masih awam dalam membuat laporan keuangan merupakah hambatan dalam mengembangkan jenis usaha. Terdapat ketakutan dalam menggunakan modal yang tersedia.

Desa Pulang Panggung merupakandesa yang subur, hasil tanaman berlimpah. Sehingga potensi desa yang berlimpah ini dimanfaatkan oleh desa untuk usaha, seperti menjadi beras dan beberapa hasil bumi lainnya. Usaha diharapkan akan menjadi lebih maju sehingga hasil bumi ini tidak hanya dijual didalam desa Pulau Panggung saja akan tetapi bisa dijual keluar desa juga.

\section{METODE KEGIATAN}

Kegiatan ini dilakukan di desa Pulau Panggung Kecamatan Talang Empat Bengkulu Tengah pada hari Senin tanggal 9 Desember 2019 Yang diikuti oleh Kepala Desa dan perangkat, warga desa dan seluruh perangkat Bumdes. Masih kurangnya pemahaman pengelolaan keuangan dan akuntansi bumdes pada desa Pulau Panggung, 
terlihat dari pertanyaan awal yang diajukan kepada peserta dan ketika mengecek laporan keuangan yang belum sesuai dengan standar yang berlaku yaitu Standar Akuntansi Keuangan Entitas Tanpa Akuntan Publik (SAK-ETAP). Adapaun langkah untuk mengatasi kendala ini kami memberikan lokakarya tentang laporan keuangan secara dasar, dan bagaimana pengelolaan keuangan serta bentuk dari laporan keuangan yang sesuai SAK ETAP. Selama Lokakarya peserta boleh langsung bertanya, hal ini diharapkan peserta yang belum paham langsung mendapat jawaban pada waktu itu juga sehingga peserta dapat menyimak materi lebih dalam, Kami juga memperagakan cara meng-input laporan keuangan sampai laporan keuangan itu jadi menggunakan contoh kasus yang sudah kami siapkan. Jadi tidak hanya materi yang diberikan akan tetapi praktik secara langsung juga kami berikan. Setelah memberikan seminar kami pun memberikan pendampingan secara terus menerus sehingga Pulau Panggung menjadi desa yang mandiri dalam mengelola keuangannya.

\section{HASIL DAN PEMBAHASAN}

\section{a. Kegiatan Lokakarya}

Kegiatan pelaksanaan ini merupakan pelaksanaan pengabdian masyarakat yang merupakan serangkaian Tridharma Perguruan Tinggi Fakultas Ekonomi Universitas Dehasen Bengkulu. Sebelum diadakannya kegiatan pengabdian dilakukan observasi awal, dimana fokus mengetahui profil desa, luas desa, potensi desa, dan bisnis yang dijalankan Bumdesa. Selanjutnya kami berkoordinasi dengan pihak Kepala Desa dan Ketua Bumdesnya tentang kegiatan yang akan dilakukan.Kegiatan ini dimulai pada jam 09.00 sampai jam 13.00 WIB didesa Pulau Panggung Kecamatan Talang Empat Bengkulu Tengah.

Awal pemberian lokakarya kami melakukan tes awal dengan memberikan pertanyaan dasar tentang laporan keuangan, hal ini dilakukan untuk mengukur seberapa paham perserta terhadap laporan keuangan dan mengecek bentuk laporan keuangan yang ternyata desa Pulau Panggung hanya memiliki buku kas saja dan neraca 
seadanya. Selanjutnya baru kami memberikan materi penjelasan tentang apa itu laporan keuangan, bentuk laporan keuangan, penjelasan kenapa kita harus membuat laporan keuangan, selanjutnya bagaimana laporan keuangan dan bagaimana bentuk laporan keuangan berdasarkan standar keuangan yang berlaku yaotu menggunakan SAKETAP. Setidaknya Laporan keuangan yang harus ada pada setiap kegiatan usaha pada Bumdes yaitu Neraca dan Laporan Laba Rugi. Neraca merupakan bagian dari laporan keuangan, dimana neraca ini menunjukan posisi keuangan BUMDes pada akhir periode. Begitu juga laporan laba rugi terdapat penjabaran pendapatan dan beban BUMDes sehingga menghasilkan laba atau rugi bersih.

Kegiatan Tanya jawab pun kami persilahkan ketika pemberian materi, hal ini dilakukan karena menurut hasil tes pertanyaan dasar laporan keuangan masih banyak yang belum paham tentang laporan keuangan terutama pihak pengelola BUMDes. Sehingga diharapkan metode tersebut membuat peserta menjadi lebih paham terhadap materi yang diberikan.

\section{Berikut foto kegiatan lokakarya}

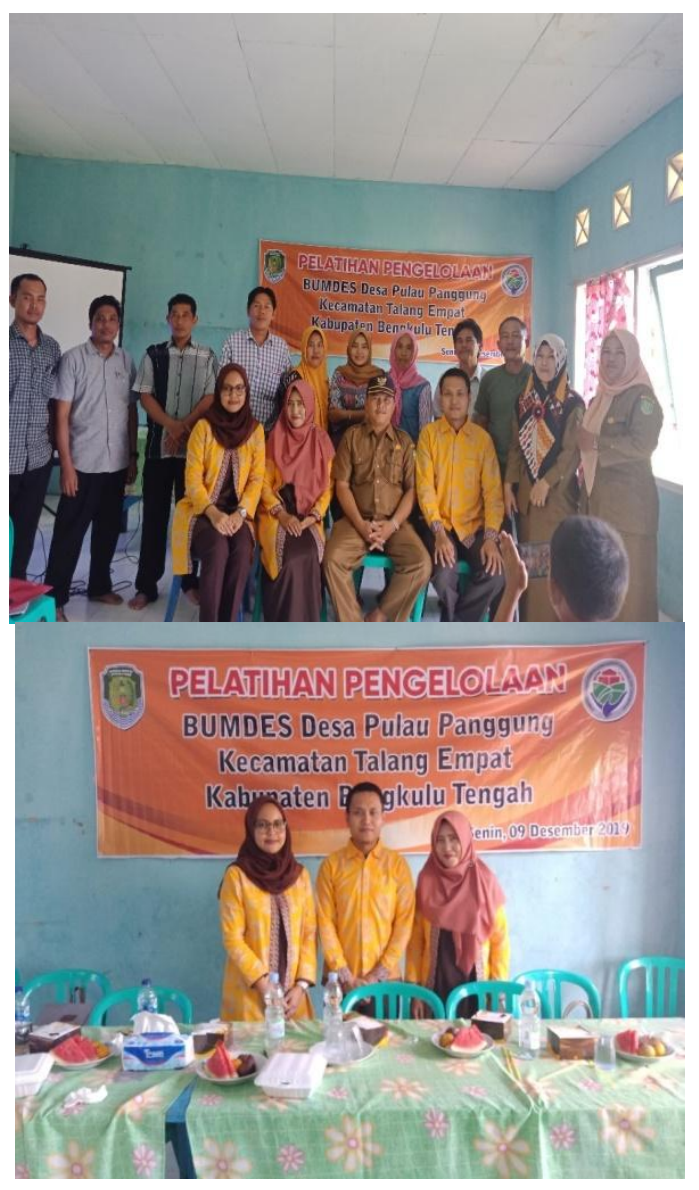

\section{b. Menelaah Permasalahan}

Berdasarkan survei dan wawancara awal dengan aparat desa dan masyarakat, salah satu permasalahan yang dihadapi dalam pengelolaan BUMDes adalah terkait dengan pengelolaan keuangan, khususnya tentang pengeloaan sumber dana, 
pencatatan dan penyajian laporan keuangan yang akuntabel. Oleh karena itu kegiatan pengabdian ini akan fokus kepada : 1. Memberikan Sosialisasi tentang pentingnya pengelolaan manajemen keuangan BUMDes. 2. Memberikan Pelatihan penyusunan laporan keuangan BUMDes.

Dari observasi awal terlihat pencatatan laporan keuangan hanya berupa buku kas dan catatan dilakukan secara manual dan ada yang menggunakan computer (Ms.Excel) dan ketika diberikan tes awal sebelum lokarya hasil menunjukan peserta belum memahami lapran keuangan itu sendiri. Penerapan akuntansi dalam laporan keuangan menjadi salah satu komponen mutlak yang harus dimiliki oleh koperasi jika mereka ingin mengembangkan usahanya.(Yusmaniart \& Ekowati, 2019) Selanjutnya untuk memperkuat pemahaman desa Pulau Panggung terhadap laporan keuangan maka kami memberikan materi laporan keuangan dasar, serta langsung mempraktekan menggunakan aplikasi Ms. Excel yang sudah kami siapkan. Selanjutnya memberikan materi pemahaman pentingnya untuk memahami laporan keuangan yang sesuai SAK-ETAP, dimana laporan keuangan berdasarkan SAK ETAP adalah:

\section{Neraca}

Neraca merupakan bagian dari laporan keuangan suatu perusahaan yang dihasilkan pada suatu periode akuntansi yang menunjukkan posisi keuangan perusahaan pada akhir periode tersebut.

Neraca minimal mencakup pospos berikut :

1. Kas dan setara kas;

2. Piutang usaha dan piutang lainnya;

3. Persediaan;

4. Properti investasi;

5. Aset tetap;

6. Aset tidak berwujud;

7. Utang usaha dan utang lainnya;

8. Aset dan kewajiban pajak;

9. Kewajiban diestimasi;

10.Ekuitas.

2. Laporan laba rugi

Laporan Laba Rugi bertujuan menyajikan laba rugi suatu entitas yang merupakan kinerja keuangan dalam periode tertentu seperti pendapatan, 
beban keuangan, beban pajak, laba atau rugi neto.Laporan laba rugi minimal mencakup pos-pos sebagai berikut :

1. Pendapatan;

2. Beban keuangan;

3. Bagian laba atau rugi dari investasi yang menggunakan metode ekuitas;

4. Beban pajak;

5. Laba atau rugi neto.

\section{Laporan perubahan ekuitas}

Menyajikan laba atau rugi entitas untuk suatu periode, pos pendapatan dan beban yang diakui secara langsung dalam ekuitas untuk periode tersebut, pengaruh perubahan kebijakan akuntansi dan koreksi kesalahan yang diakui dalam periode tersebut, dan (bergantung pada format laporan perubahan ekuitas yang dipilih oleh entitas) jumlah investasi oleh, dan dividen dan distribusi lain ke pemilik ekuitas selama periode tersebut. Laporan perubahan ekuitas juga menunjukkan :

(i) Seluruh perubahan dalam ekuitas, atau

(ii) Perubahan ekuitas selain perusahaan yang timbul dari transaksi dengan pemilik dalam kapasitasnya sebagai pemilik.

4. Laporan arus kas

Laporan arus kas menyajikan informasi perubahan historis atas kas dan setara kas entitas, yang menunjukkan secara terpisah perubahan yang terjadi selama satu periode dari aktivitas operasi, investasi, dan pendanaan.

5. Catatan atas laporan keuangan

Berisi informasi sebagai tambahan informasi yang disajikan dalam laporan keuangan. Catatan atas laporan keuangan memberikan penjelasan naratif atau rincian jumlah yang disajikan dalam laporan keuangan dan informasi pos-pos yang tidak memenuhi kriteria pengakuan dalam laporan keuangan.

SAK ETAP paragraf 2.1 menyatakan bahwa tujuan laporan keuangan adalah menyediakan informasi posisi keuangan, kinerja keuangan, dan laporan arus kas suatu entitas yang bermanfaat bagi sejumlah besar pengguna dalam pengambilan keputusan ekonomi oleh siapapun yang tidak dalam posisi dapat meminta laporan keuangan khusus untuk memenuhi kebutuhan 
informasi tertentu. Dalam memenuhi tujuannya, laporan keuangan juga menunjukkan apa yang telah dilakukan manajemen (stewardship) atau pertanggungjawaban manajemen atas sumber daya yang dipercayakan kepadanya.

Pembentukan Badan Usaha Milik Desa (BUMDes) dimaksudkan bukan saja untuk menjadi motor penggerak roda-roda perekonomian desa tetapi juga dimaksudkan sebagai sumber pendapatan Desa. Untuk itu pengelolaan keuangan desa ini harus ditangani secara profesional, sehingga kedua maksud tersebut dapat dicapai (Soleh, Chabib dan Heru Rochmansyah,2014).

\section{Foto kegiatan Tanya jawab peserta}

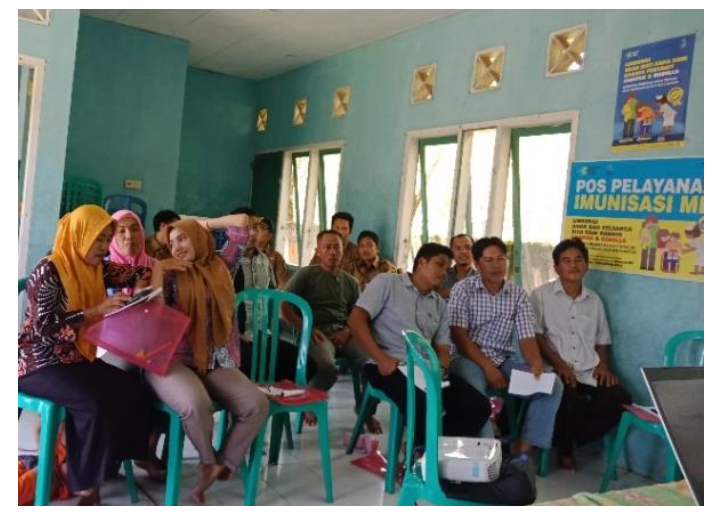

\section{Solusi yang Diberikan}

Dengan adanya lokakarya ini diharapkan menjadi jawaban untuk masalah yang dihadapi oleh pihak desa Pulau Panggung dalam menjalankan BUMDesnya. Memberikan lokakarya materi tentang laporan keuangan dan akuntansi bumdes. Dimana penjelasan dimulai dari menjelaskan anggaran, akun-akun yang terkait dalam anggaran tersebut, menjelaskan dimana letak anggaran jika terdapat penerimaan dana dari dana desa. Selanjutnya menjelaskan apa itu laporan keuangan, jenis laporan keuangan, dan langsung mempraktikan laporan keuangan tersebut dengan study kasus yang sudah dipersiakan dan mengerjakan lewat Ms excel. Selanjutnya kami memberikan pendampingan secara berkelanjutan sehingga desa ini mampu untuk mandiri mengelola keuangannya.

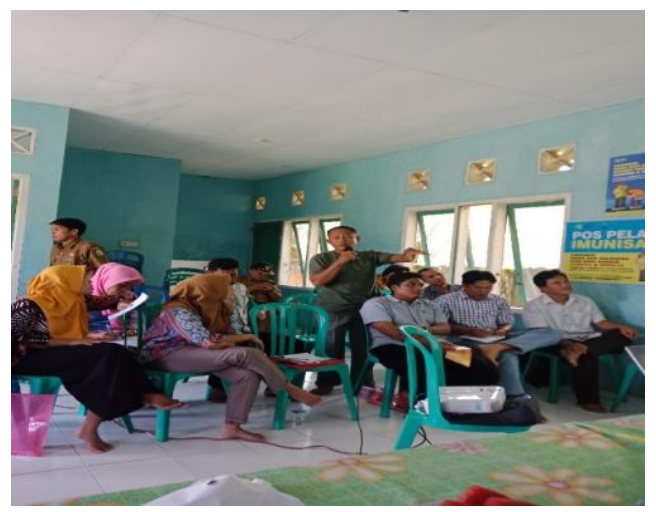




\section{Penutup}

Dari hasil kegiatan lokakarya pengelolaan keuangan dan akuntansi Bumdes di desa Pulau Panggung dapat disimpulkan bahwa masih terdapat kekurangan dalam beberapa bagian seperti: Sumber Daya Manusia yang mumpuni untuk melakukan unit bisnis bumdes, kurangnya pemahaman tentang laporan keuangan dan bagaimana pemahaman laporan keuangan sebagai alat komunikasi para stakeholder, takut menggunakan modal yang sudah diberikan, Belum terampilnya pengelola Bumdes terhadap aplikasi Ms. Excel dan yang terakhir pencatatan transaksi harus tetap didampingi sampai mereka dapat memenuhi syarat membuat laporan keuangan yang sesuai dengan standar peraturan pelaporan Bumdes.Dari kegiatan itu dapat disimpulkan metode yang digunakan yaitu memberikan penyuluhan, diskusi, pendampingan.

Setelah melalui program pendampingan yang dilakukan oleh tim, maka mitra binaan telah mencapai beberapa kemajuan. Namun demikian, pendampingan tersebut tidak bisa berhenti setelah kegiatan selesai. Disarankan, pemerintah desa Pulau Panggung untuk lebih proaktif melakukan konsultasi kepada tim pendamping atau pihak lain yang kompeten, agar BUMDesnya lebih maju dan berkembang.

\section{DAFTAR PUSTAKA}

Chabib Sholeh dan Heru Rochmansjah, 2010, Pengelolaan Keuangan dan Aset Daerah Sebuah Pendekatan Struktural Menuju Tata Kelola Pemerintahan Yang Baik. Bandung: Fokusmedia

Hidayat Taufik, Pujiati. 2018.Pendampingan Penyusunan Laporan Keuangan Pada Badan Usaha Milik Desa (Bumdes) Lestari Desa Bandung Kecamatan Diwek Jombang.COMVICE, Vol 2 No 1, April 2018.

Peraturan Menteri Desa, Pembangunan Daerah Tertinggal, dan Transmigrasi Nomor 4 Tahun 2015 tentang Pendirian, Pengurusan dan Pengelolaan, dan Pembubaran Badan Usaha Milik Desa.

Ikatan Akuntan Indonesia (IAI). 2016, Standar Akuntansi Keuangan Entitas Tanpa Akuntabilitas Publik. Dewan Standar Akuntansi Keuangan, Jakarta.

Yusmaniart, Y., \& Ekowati, S. (2019). Laporan Keuangan Koperasi Berbasis Media Excel For Accounting (EFA). Jurnal Pengabdian Masyarakat Bumi Raflesia, 2(1), 127-137. 